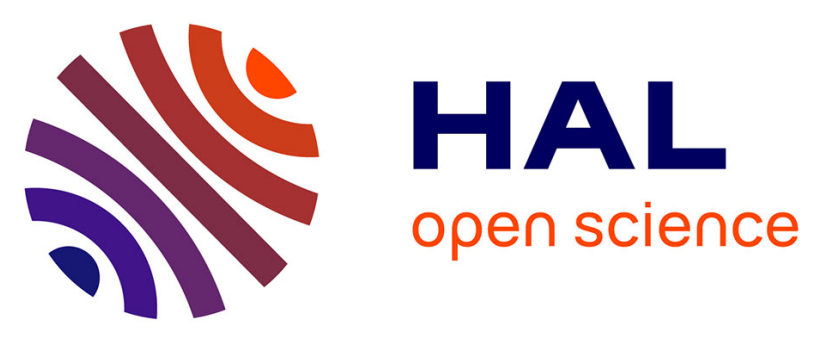

\title{
Fine characterization of intrahepatic NK cells expressing natural killer receptors in chronic hepatitis $\mathrm{B}$ and $\mathrm{C}$.
}

Paula Bonorino, Muhammad Ramzan, Xavier Camous, Tania

Dufeu-Duchesne, Marie-Ange Thélu, Nathalie Sturm, Aurélie Dariz, Christiane Guillermet, Martine Pernollet, Jean-Pierre Zarski, et al.

\section{To cite this version:}

Paula Bonorino, Muhammad Ramzan, Xavier Camous, Tania Dufeu-Duchesne, Marie-Ange Thélu, et al.. Fine characterization of intrahepatic NK cells expressing natural killer receptors in chronic hepatitis B and C.: NK cells in chronic hepatitis C and hepatitis B. Journal of Hepatology, 2009, 51 (3), pp.458-67. 10.1016/j.jhep.2009.05.030 . inserm-00405723

\section{HAL Id: inserm-00405723 https://www.hal.inserm.fr/inserm-00405723}

Submitted on 21 Jul 2009

HAL is a multi-disciplinary open access archive for the deposit and dissemination of scientific research documents, whether they are published or not. The documents may come from teaching and research institutions in France or abroad, or from public or private research centers.
L'archive ouverte pluridisciplinaire HAL, est destinée au dépôt et à la diffusion de documents scientifiques de niveau recherche, publiés ou non, émanant des établissements d'enseignement et de recherche français ou étrangers, des laboratoires publics ou privés. 


\title{
Fine Characterization of Intra-hepatic NK cells Expressing Natural Killer Receptors in Chronic Hepatitis B and C
}

Paula Bonorino ${ }^{1,2^{*}}$, Muhammad Ramzan ${ }^{1,2^{*}}$, Xavier Camous ${ }^{1,2}$, Tania DufeuDuchesne $^{1,2}$, Marie-Ange Thélu ${ }^{1,2}$, Nathalie Sturm ${ }^{1,2}$, Aurélie Dariz ${ }^{1,2}$, Christiane Guillermet $^{1,2}$, Martine Pernollet ${ }^{1,2}$, Jean-Pierre Zarski ${ }^{1,2}$, Patrice N. Marche ${ }^{1,2}$, Vincent Leroy $^{1,2}$ and Evelyne Jouvin-Marche ${ }^{1,2}$.

\section{Addresses:}

1 Institut National de la Santé et de la Recherche Médicale (INSERM), Unité 823, Grenoble, France.

${ }^{2}$ Université Joseph Fourier-Grenoble I, Faculté de Médecine, Institut Albert Bonniot, UMR-

U823, Grenoble, France

* PB and MR have contributed equally to this work

Corresponding author: PN MARCHE

Centre de recherche INSERM/UJF U823-Equipe IAPC Institut Albert Bonniot

BP170-38042, Grenoble Cedex 09, France.

Patrice.Marche@ujf-grenoble.fr

Tel: +334765494 95. Fax: +33476549454

\begin{abstract}
Background/Aims. The fate of intrahepatic NK cell subsets in the course of HCV and HBV infections is not clearly understood.

Methods. Blood and intrahepatic CD56 ${ }^{+}$NK cell subsets (expressing NKG2A, CD158a,h or CD158b,j receptors) from HCV or HBV patients were quantified by flow cytometry and localized by immunohistochemistry in liver biopsies.

Results A significant reduction in NK cell frequency and a quantitative imbalance between CD56 $6^{\text {bright }}$ and CD56 ${ }^{\mathrm{dim}}$ subsets were observed in chronic HCV patients as compared to HBV patients, underlining that the inflammatory environment is not the only cause of these phenomena. The proportions of intra-hepatic NK cells expressing either NKG2A, and/or CD158a,h, CD158b,j differed significantly between HCV and HBV patients. A higher frequency of perforin among intra-hepatic $\mathrm{CD} 56^{+} \mathrm{CD}^{-}$cells was observed in $\mathrm{HCV}$ compared to HBV patients. Double immunohistochemical staining showed that $\mathrm{CD}_{56}{ }^{+} \mathrm{CD}{ }^{-}$cells were localized within necrotic areas. Immune monitoring of circulating CD56 subsets revealed that $\mathrm{CD}^{-} \mathrm{CD} 56^{\text {bright }} \mathrm{NKG} 2 \mathrm{~A}^{+}$and $\mathrm{CD} 3{ }^{-} \mathrm{CD} 56^{\mathrm{dim}} \mathrm{NKG} 2 \mathrm{~A}^{+}$cells were positively correlated with the necro-inflammatory score and inversely correlated with viral load, respectively, in $\mathrm{HCV}$ patients.

Conclusions. HCV and HBV affect NK cell subsets according to the status of the diseases, especially $\mathrm{CD}^{-}{ }^{-} \mathrm{CD} 56^{\mathrm{dim}} \mathrm{NKG} 2 \mathrm{~A}^{+}$and $\mathrm{CD} 3^{-} \mathrm{CD} 56^{\text {bright }} \mathrm{NKG} 2 \mathrm{~A}^{+}$cells, may be of interest for disease monitoring.
\end{abstract}




\section{Introduction:}

Hepatitis C virus (HCV) and hepatitis B virus (HBV) are preferentially hepatotropic, not directly cytopathic, capable of provoking acute and chronic necro-inflammatory liver injury and are the most common causes of liver disease worldwide [1]

The various strategies that many viruses have evolved to evade natural killer (NK) cell effector functions illustrate the central role for these cells in early host defense against viral infections [2, 3]. It is known that both $\mathrm{HCV}$ and $\mathrm{HBV}$, impair human and murine NK cell activity $[4,5]$. HCV may inhibit the activation of Interferon Regulatory Factor (IRF) [6] and can interfere with PKR kinase function [7] which can activate NK cells. In the case of HBV, both IRF and PKR appear to mediate signals that modulate viral replication in $\operatorname{IRF}\left(\left(^{-/}\right)\right.$or $\operatorname{PKR}\left(\left(^{-/}\right)\right.$ transgenic mice [8]. In contrast to other viruses, $\mathrm{HCV}$ and HBV induce sustained HLA class I expression on infected cells $[9,10]$. The inhibitory effect of NK cells on HCV replication in cultured human hepatocytes [11] suggests that NK cells might be able to contribute to the control of these infections. In the early phase of HBV infection, the host's response to HBV mediates the activation of NK cells which produce IFN- $\alpha$ and are able to lyse infected cells by TRAIL-mediated death of hepatocytes [12].

Despite multiple studies on the functional potential of NK cells in persistent $\mathrm{HCV}$ and HBV infections [13-15], evidence of a role for NK cell defects in these chronic infections remains open for debate. It is established that NK cell frequencies in HCVinfected patients are lower than those observed in the un-infected population [14-16]. According to the surface expression level of CD56, NK cells can be divided into two subsets with important functional distinctions. The vast majority of NK cells displays a moderate level of CD56 (CD56 $\left.{ }^{\mathrm{dim}}\right)$ with a marked cytotoxicity potential, while, a small proportion harbors a high CD56 expression level (CD56 $6^{\text {bright }}$ ) having a greater capacity to secrete cytokines [17, 18]. Recently, it was reported that the frequency of peripheral blood cytolytic CD56 ${ }^{\mathrm{dim}} \mathrm{NK}$ cells is decreased in HCV infected patients [15]. Less is known about expression of HLA class I specific NK receptors (NKRs). NKRs are subdivided into two major families. The first family is composed of killer immunoglobulin-like receptors (KIR), such as CD158 molecules and LIR1/ILT2 (leukocyte Ig-like receptor $1 / \mathrm{Ig}$-like transcript 2) which recognize classical HLA-A, -B and -C class I molecules. The second family includes $\mathrm{C}$ type lectin-like molecules, such as, NKG2A that associate with CD94 to form inhibitory heterodimer that recognize non-classical HLA-E molecules. .

Here, we have performed flow cytometry analyses and detailed histological studies on liver biopsies to quantify and localize the $\mathrm{CD}^{2} 6^{+}$cells in the different histological areas. Furthermore we investigated the perforin contents of different NK cells subset as markers of their cytotoxicity. Then, we searched for relationship between NK cells subset distribution and the clinical parameters.

\section{Materials and Methods}

\section{Patients.}

Chronic hepatitis $\mathrm{C}(\mathrm{n}=28)$ and B patients $(\mathrm{n}=19)$ seen in the Grenoble University Hospital between 2005 and 2007, were included in this study. Their main characteristics were analyzed as previously described [19] and are summarised in Table 1. For immunohistochemical studies, $\mathrm{HCV}(\mathrm{n}=6)$ and $\mathrm{HBV}$ patients $(\mathrm{n}=6)$ patients were classed as have low necro-inflammatory grading (Metavir-A1, 3 patients) and high necroinflammatory grading (Metavir-A3, 3 patients) by the French Metavir Scoring System. Blood samples from healthy volunteers $(n=18)$ were obtained from the regional Etablissement Français du Sang (La Tronche, France).

Isolation of intra-hepatic cells.

Liver biopsies obtained by using $1.5 \mathrm{~mm}$ diameter disposable biopsy needle were processed for histopathological examination and immunological analysis. Cells were prepared as described previously [20, 21].

\section{Monoclonal antibodies, Immunostaining and} Flow Cytometry.

The monoclonal antibodies used were anti-CD3 PC7 (UCHT1), anti-CD56 PE (NCAM16.2), and anti-Perforin FITCconjugated ( $(\mathrm{G} 9)$, from Becton-Dickinson Biosciences (Pont de Claix, France). AntiCD158a,h+-PE (EB6), anti-CD158b1,b2,j-PE (GL183), anti-NKG2A(CD159A)-PE (Z199) were obtained from Beckman Coulter France (Villepinte, France). Immunostaining and flow 
cytometric analysis were done as described previously $[19,22]$.

\begin{tabular}{|c|c|c|}
\hline & $\begin{array}{c}\mathbf{H C V}+\text { patients } \\
(n=28)\end{array}$ & $\begin{array}{c}\mathbf{H B V}+\text { patients } \\
(n=19)\end{array}$ \\
\hline \multicolumn{3}{|l|}{ Demography } \\
\hline$\overline{M a l e, n(\%)}$ & $17(61 \%)$ & $10(53 \%)$ \\
\hline Age $(y)^{*}$ & $50(26-64)$ & $38(17-63)$ \\
\hline Plasma Viral Load (logIU/mL) & $6.2 \pm 0.4$ & $4.5 \pm 1.9$ \\
\hline Serum ALT (UI/mL) & $73.8 \pm 53.1$ & $42.7 \pm 27.8$ \\
\hline \multicolumn{3}{|l|}{ Liver Histology** } \\
\hline Metavir Activity Score, n(\%) & $n=27 * * *$ & $n=11 * * *$ \\
\hline 0 & 0 & $1(9 \%)$ \\
\hline 1 & $14(50 \%)$ & $6(55 \%)$ \\
\hline 2 & $9(32 \%)$ & $4(36 \%)$ \\
\hline 3 & $4(14 \%)$ & 0 \\
\hline unknown & 1 & 8 \\
\hline Metavir Fibrosis Score, n(\%) & $n=28$ & $n=11 * * *$ \\
\hline 0 & $2(7 \%)$ & $3(27 \%)$ \\
\hline 1 & $12(43 \%)$ & $6(55 \%)$ \\
\hline 2 & $6(21 \%)$ & $2(18 \%)$ \\
\hline 3 & $3(11 \%)$ & 0 \\
\hline 4 & $5(18 \%)$ & 0 \\
\hline unknown & 0 & 8 \\
\hline
\end{tabular}

* Median (Range)

* Number of cases / total (\%)

Note that for

experiments described could not be performed for every single patien

ALT: Alanine AminoTransferase

Table1. Demographic, biochemical and clinical characteristics of chronic HCV and HBV infected patients studied by flow cytometry.

\section{Immunohistochemical Staining.}

Single and double CD56/CD3 immunohistochemical staining was performed on an automatic immunostainer (Benchmark XT, Ventana, Tucson, AZ, USA) [19, 22]. Briefly, slides were incubated with a primary anti-CD56 antibody (Clone 1B6 Novacastra, Newcastel, United Kingdom), followed by an immunodetection with DAB (diaminobenzidine) I-view Kit (Ventana Medical Systems, Tucson, Arizona, USA). $\mathrm{CD}^{+} 6^{+}$cells were counted in 40 randomly selected fields per slide with the help of LUCIA software (Laboratory Universal Computer Image Analysis, version 5.0, Laboratory Imaging, Prague, Czech) at high magnification (X400) [20]. Several parameters were scored separately including total lymphocytes, $\mathrm{CD}^{2} 6^{+}$cells, and association of $\mathrm{CD} 6^{+}$cells with piece meal necrosis or lobular necrosis as well as their localization in the fibrotic tissues and in the nodular parenchyma. The numbers of cells were expressed as Unit defined as 40 fields (400X) equivalent of an area of $2.74 \mathrm{~mm}^{2}$.

For double immunostaining, antigen retrieval was performed with $\mathrm{CC} 1$ basic buffer pre-treatment for 60 minutes, followed by incubation with the primary anti-CD56 antibody and detected with Ultra-View Diaminobenzidine multimer kit. For $\mathrm{CD} 3$ detection, a second $\mathrm{CC} 1$ pre-treatment was applied on the same slides followed by incubation with the primary antibody (polyclonal rabbit CD3, 1/100, Dako A0452) incubation with a secondary antibody (biotinylated goat anti-rabbit $\operatorname{IgG}, 1 / 750$, Jackson Immunoresearch 111-065-003) was detected with Ultra-View Alkalin Phosphatase red multimer kit and counterstaining (Conterstain 2) for 5 minutes.

The non-parametric Wilcoxon, Spearman and Mann-Whitney U-tests were performed for comparisons between the groups of patients and controls as previously described [19].

\section{Results}

\section{Decreased frequency of blood and intra-hepatic NK cells in HCV patients.}

The flow cytometric gating strategy used to identify the different subsets of NK cells is depicted in Fig.1. Phenotypic analysis of PBMCs from HCV patients demonstrated that the proportion of $\mathrm{CD} 3^{-} \mathrm{CD} 56^{+} \mathrm{NK}$ cells relative to lymphocyte populations was significantly decreased as compared to healthy donors $(8.6 \%$ vs $13.3 \%, p<0.05)($ Fig.2A). Examination of the $\mathrm{CD}^{-} \mathrm{CD} 56^{\mathrm{dim}}$ and $\mathrm{CD} 3^{-} \mathrm{CD} 56^{\text {bright }}$ cells distribution revealed that the frequency of $\mathrm{CD}^{-}$ CD56 ${ }^{\text {bright }}$ cells was significantly increased (10.0 $\%$ vs $6.0 \%, p<0.05$ ) (Fig.2B) while the frequency of $\mathrm{CD} 3^{-} \mathrm{CD} 56^{\mathrm{dim}}$ cells was significantly reduced $(90.0 \%$ vs $94.0 \%, p<0.05)$ (Fig.2C) in HCV patients as compared to healthy donors. These results are similar to those described by other investigators [14-16]. No such frequency differences were observed between HBV patients and healthy for either $\mathrm{CD}^{-}{ }^{-} \mathrm{CD} 56^{+} \mathrm{NK}$ cells $(12.3 \%$ vs $13.3 \%)$, $\mathrm{CD}^{-}$ CD56 ${ }^{\text {bright }}$ cells $(6.0 \%$ vs $6.0 \%)$, or CD3 ${ }^{-}$D $56^{\mathrm{dim}}$ cells ( $94.0 \%$ vs $94.0 \%)$.

In HCV patients, the proportion of total intrahepatic $\mathrm{CD}^{-}{ }^{-} \mathrm{CD} 56^{+}$NK cells appeared dramatically lower than that of their blood counterparts $(5.1 \%$ vs $8.6 \%, p<0.005)$ (Fig.2A). Again, this feature was not found in $\mathrm{HBV}$ patients where the proportion of intra-hepatic CD $3{ }^{-} \mathrm{CD} 56^{+} \mathrm{NK}$ cells was similar to that of their blood counterparts $(15.2 \%$ vs $12.3 \%, N S)$ and thus significantly higher than that observed in the liver from $\mathrm{HCV}$ patients $(15.2 \%$ vs $5.1 \%$, $p<0.005)$. The low number of intra-hepatic CD3 $\mathrm{CD}^{2} 6^{+}$cells precluded accurate analysis of the 
proportion of $\mathrm{CD}^{-} \mathrm{CD} 56^{\text {bright }}$ vs $\mathrm{CD} 3^{-} \mathrm{CD} 56^{\mathrm{dim}}$ cells in HCV patients.
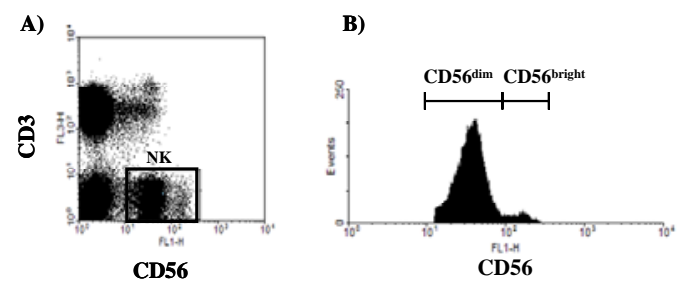

C) CD158a,h D) CD158b,j

E) NKG2A
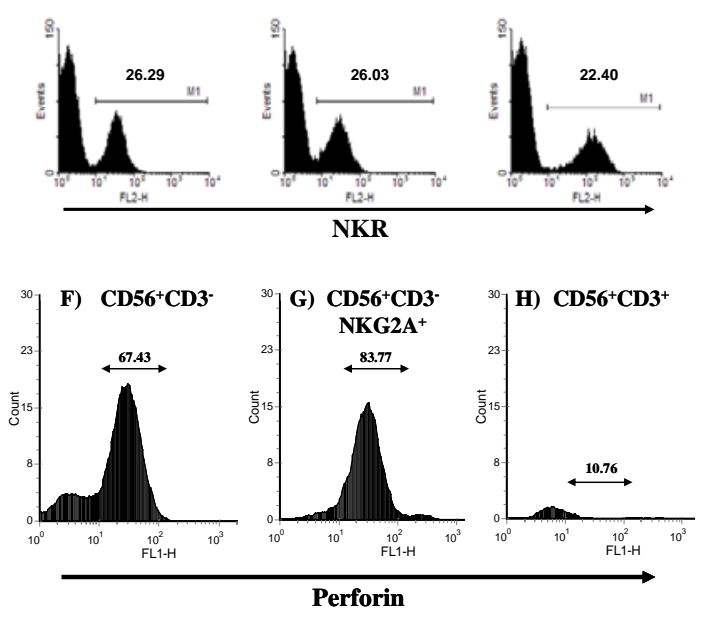

Figure 1. Expression of Natural Killer Receptors (NKRs) by NK cells

Representative four-color flow cytometry analysis for peripheral blood lymphocytes is shown for a patient chronically infected by the Hepatitis $\mathrm{C}$ virus. A) Dot plot representation of CD3 and CD56 double staining used to estimate the frequency of NK cells (boxed $\mathrm{CD} 3^{-} \mathrm{CD} 56^{+}$); B) Histogram of the CD56 ${ }^{+}$cells defining the CD56 $6^{\mathrm{dim}}$ and $\mathrm{CD} 56^{\text {bright }} \mathrm{NK}$ cells $\left(\mathrm{CD} 3^{-} \mathrm{CD} 56^{+}\right)$; C) CD158a,h; D) CD158b,j and E) NKG2A expressions respectively. Histogram of perforin cells in $\mathrm{CD}^{-} \mathrm{CD}^{-} 6^{+}$(F), $\mathrm{CD}^{-} \mathrm{CD} 56^{+} \mathrm{NKG}^{-} \mathrm{A}^{+}$ $(\mathrm{G})$ and $\mathrm{CD}^{+} \mathrm{CD}^{+} 6^{+}$cells $(\mathrm{H})$.

Nevertheless, this analysis when conducted for HBV patients revealed that the proportion of intra-hepatic $\mathrm{CD}^{-} \mathrm{CD} 56^{\text {bright }}$ cells was significantly higher $(6.0 \%$ vs $19.5 \%, p<0.005)$ than those observed in the peripheral blood while the proportion of intra-hepatic $\mathrm{CD}^{-}$ CD56 ${ }^{\mathrm{dim}}$ cells was significantly lower $(94.0 \%$ vs $80.5 \%, p<0.005)$ than in the peripheral blood (Fig.2B,C).

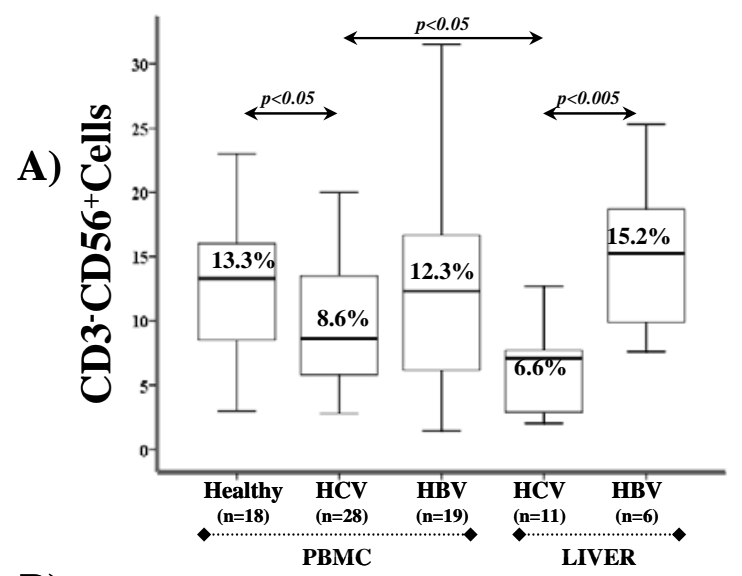

B)
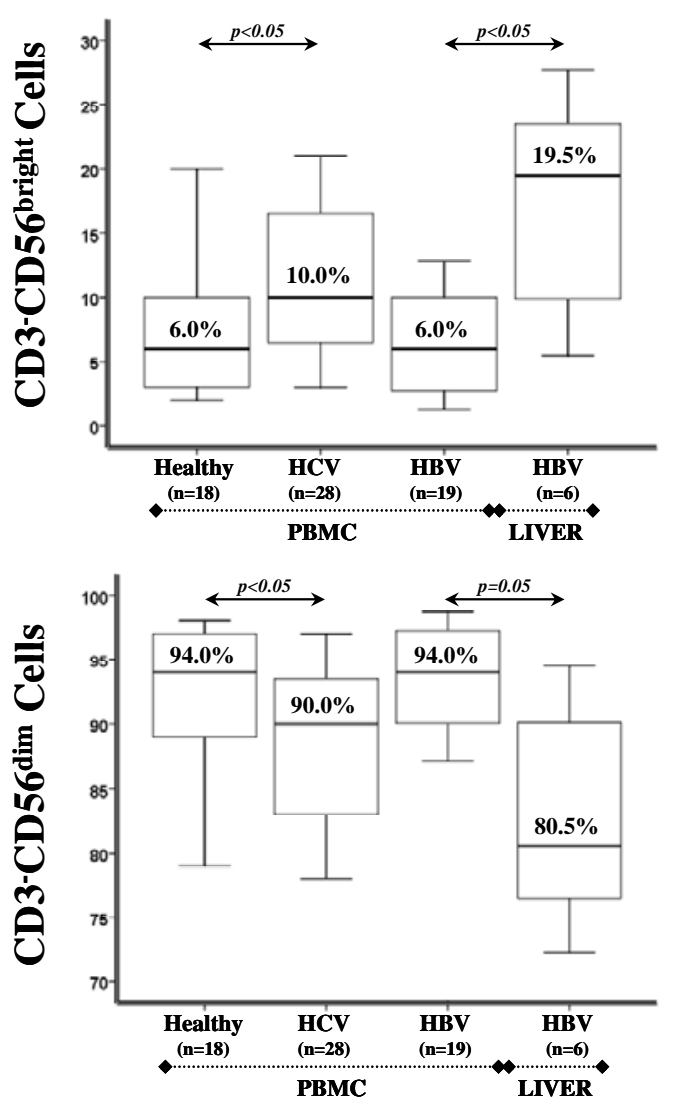

Figure 2. Frequency of blood and intrahepatic NK cells in Chronic HCV or HBV patients

The frequency of (A) NK cells $\left(\mathrm{CD}^{-} \mathrm{CD}^{-} 6^{+}\right)(\mathbf{B})$ CD56 ${ }^{\text {dim }}$ within $\mathrm{CD} 3^{-} \mathrm{CD} 56^{+}$cells $(\mathbf{C})$ CD56 $6^{\text {bright }}$ within $\mathrm{CD}^{-} \mathrm{CD}^{-} 6^{+}$cells was evaluated by flow cytometry in the blood and/or in liver of healthy, $\mathrm{HCV}^{+}$and $\mathrm{HBV}^{+}$patients. Data are represented as boxplots showing medians (horizontal lines), upper and lower quartiles (boxes) and extreme values (whiskers). 


\section{Intrahepatic localization of $\mathrm{CD}^{+} 6^{+}$cells in $\mathrm{HCV}$ and $\mathrm{HBV}$ patients.}

In order to precisely quantify and localise $\mathrm{CD}^{2} 6^{+}$cells in different intra-hepatic areas (nodular parenchymatous areas and necroinflammatory lesions) immunohistochemistry was performed. We selected 6 chronic $\mathrm{HCV}$ patients with A1 $(n=3)$ and A3 $(n=3)$ Metavir scores and 6 chronic histologically-matched HBV patients. The presence of $\mathrm{CD} 56^{+}$cells was detected essentially in piecemeal and lobular necrosis (Fig.3 A, B, C, D). CD56 ${ }^{+}$cell density were significantly lower in the liver of $\mathrm{HCV}$ patients compared to HBV patients (69 vs134 $p<0.05$ ) (Fig.3E). Strikingly, the density of CD56 cells was significantly higher in $\mathrm{HCV}$ patients compared to HBV patients (on average 2122 vs 583 cells $/ \mathrm{U}, p<0.005)$. Thus, the percentage of $\mathrm{CD}^{+} 6^{+}$cells among the total infiltrating immune cells was significantly lower in $\mathrm{HCV}$ patients compared to $\mathrm{HBV}$ patients (3.6\% vs $18.4 \%, p<0.005)$.

Considering the localization of CD56 ${ }^{+}$ cells in the different histological areas, we observed that i) $\mathrm{CD}^{+} 6^{+}$cells density was significantly lower in parenchymatous areas in $\mathrm{HCV}$ patients compared to HBV patients (28 vs 114, $p<0.005$ ) (Fig.3F); and ii) $\mathrm{CD}^{+} 6^{+}$cell density was low inside the necro-inflammatory lesions (piecemeal necrosis and lobular necrosis) in both $\mathrm{HCV}$ and HBV patients. However, inside the necro-inflammatory lesions, $\mathrm{CD} 6^{+}$cells were significantly higher in $\mathrm{HCV}$ patients as compared to $\mathrm{HBV}$ patients ( 9 vs $2, p<0.005$ ) (Fig.3G).

In some cases, double immunostaining of CD56 and CD3 cells was investigated in order to distinguish between classical NK cells (CD3$\mathrm{CD}^{+} 6^{+}$and cells expressing CD3 and CD56 molecules. We observed numerous $\mathrm{CD}^{+}$ lymphocytes (red, Fig. $3 \mathrm{H}, \mathrm{I}$ ) and few $\mathrm{CD} 56^{+}$ cells (brown, Fig.3H,I) present in the fibrous areas and in necro-inflammatory lesions. Orange CD56/CD3 double-stained cells were scarce and observed in the fibrous septa only (Fig.3H).

\section{Relationship between blood and intra-hepatic $\mathrm{CD}^{-} \mathrm{CD}^{-} 6^{+} \mathrm{NK}$ cells in necro-inflammatory lesions}

In both HCV and HBV infection, intrahepatic $\mathrm{CD} 6^{+}$cells density remained constant whatever the necro-inflammatory grading (Fig.3). In contrast, the $\mathrm{CD}^{-} 6^{-}$cell density increased from A1 to A3 Metavir score, in both $\mathrm{HCV}$ and HBV patients (Table 2). Thus, the proportion of $\mathrm{CD}^{+} 6^{+}$cells among total lymphocytes decreased from A1 to A3 Metavir in both $\mathrm{HCV}$ and HBV groups. The CD56 ${ }^{+}$cell density inside the necro-inflammatory lesions was higher in Metavir-A1 than in Metavir-A3 patients in HCV groups but such difference was not found in HBV groups. With increasing necro-inflammatory activity, $\mathrm{CD} 56^{+}$cells tended to localize preferentially outside of necroinflammatory lesions in HCV patients. In both groups, peripheral $\mathrm{CD} 3{ }^{-} \mathrm{CD} 56^{+} \mathrm{NK}$ cells did not correlate with any bioclinical parameters including necro-inflammatory grade, ALT serum levels and viral load.

\section{Analysis of HLA class I specific receptors expression by NK cells.}

Among blood NK cells, expression of $\mathrm{CD} 158 \mathrm{a} / \mathrm{h}, \mathrm{CD} 158 \mathrm{~b} / \mathrm{j}$ and NKG2A did not differ between HCV patients and healthy donors. However, we detected a significant decrease of $\mathrm{NKG}_{2} \mathrm{~A}^{+}$expression in $\mathrm{HBV}$ patients as compare to HCV patients $(54.5 \%$ vs $24.7 \%, p<0.001)$ and healthy donors $(55.4 \%$ vs $24.7 \%, p<0.001)$ (Fig.4A). 


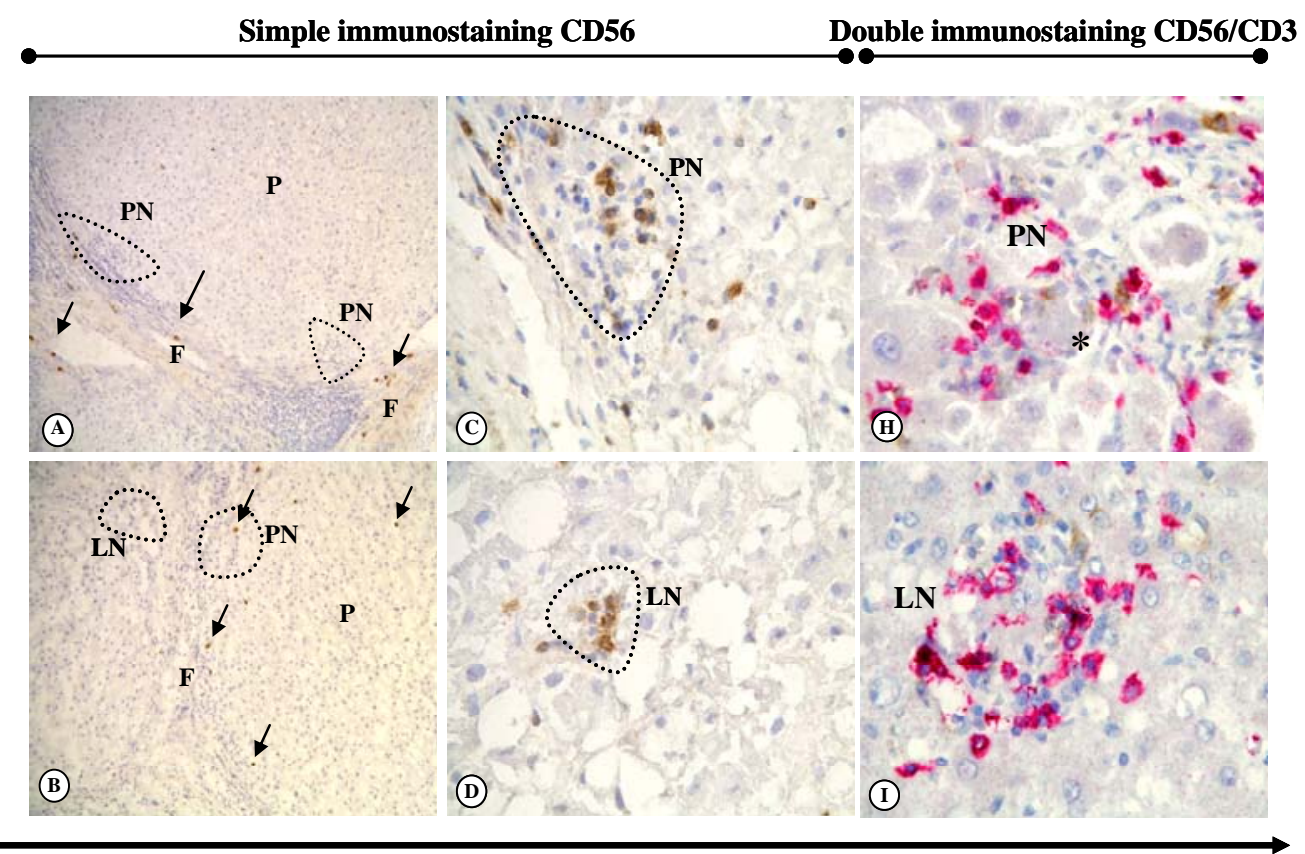

Intra-hepatic NK cells in HCV patients

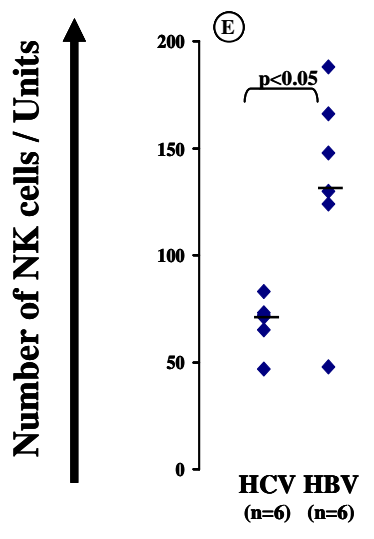

CD56 cells

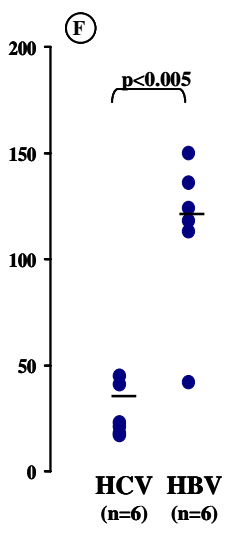

CD56 cells in Parenchyma

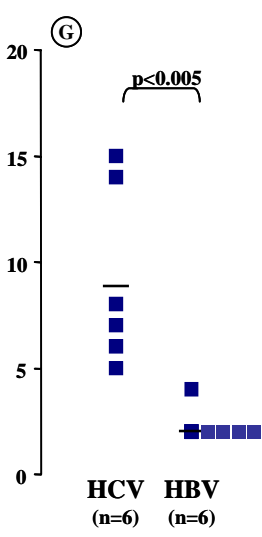

CD56 cells in
Necrosis

Figure 3. Immunohistochemical detection and quantification of intra-hepatic $\mathrm{CD}^{+}{ }^{+}$cells in hepatitis $\mathbf{C}$ or hepatitis B patients. (A) $\mathrm{CD}_{5}{ }^{+}$cells are present in the Fibrotic area (indicated by F and black arrows) of hepatitis $\mathrm{C}$ patients without localization in the Piecemeal Necrosis (PN) (Original magnification X100). (B) CD56 cells are present in the Fibrotic area and Parenchyma (indicated by $\mathrm{P}$ and black arrows) of hepatitis $\mathrm{C}$ patients with the localization in Piecemeal Necrosis (Original magnification X100). (C) Localization of $\mathrm{CD}^{+} 6^{+}$cells in the Piecemeal Necrosis (Original magnification X400) of hepatitis C patients. (D) Localization of CD $56^{+}$cells in the Lobular Necrosis (LN) (Original magnification X400). (E) Total CD56 $6^{+}$cells in both groups of patients. (F) CD56 $6^{+}$cells in Parenchyma in both groups of patients. (G) $\mathrm{CD}^{+} 6^{+}$cells in necrosis (Piecemeal and Lobular necrosis) in both groups of patients. In (E), $(\mathrm{F})$ and $(\mathrm{G})$, all the values represent a density of CD56 ${ }^{+}$ cells/unit area $=2.74 \mathrm{~mm}^{2}$ and the horizontal bar represents median values. $(\mathrm{H}) \mathrm{CD}^{+}$lymphocytes (red) and CD56 $6^{+}$lymphocytes (brown) are taking part in Parcellar Necrosis, with two CD56 cells in contact with an apoptotic body (asterisk, objective x40). (I) $\mathrm{CD}^{+}$lymphocytes (red) and CD56 ${ }^{+}$ lymphocytes (brown) inside a Lobular Necrosis (objective x 40) . 


\begin{tabular}{|c|c|c|c|c|}
\hline & \multicolumn{2}{|c|}{ Cirrhosis C } & \multicolumn{2}{|c|}{ Cirrhosis B } \\
\hline & $\begin{array}{c}\text { Metavir A1 } \\
n=3\end{array}$ & $\begin{array}{c}\text { Metavir A3 } \\
n=3\end{array}$ & $\begin{array}{c}\text { Metavir A1 } \\
n=3\end{array}$ & $\begin{array}{c}\text { Metavir A3 } \\
n=3\end{array}$ \\
\hline CD56 Cells & 68 & 69 & 134 & 134 \\
\hline CD56 Cells Lymphocytes & 1501 & 2744 & 531 & 635 \\
\hline CD56 Cells/Lymphocytes (\%) & 4.6 & 2.6 & 20.3 & 16.4 \\
\hline CD56 Cells in Parenchyma & 36 & 19 & 129 & 99 \\
\hline CD56 Cells outside Necrosis & 55 & 63 & 132 & 131 \\
\hline CD56 Cells inside Necrosis & 12 & 6 & 2 & 3 \\
\hline
\end{tabular}

All the parameters were expressed as / Unit - 1Unit $=40$ fields $(400 \mathrm{X})=2.74 \mathrm{~mm}^{2}$

Table 2. Expression of CD56+ cells by immunohistochemistry among cirrhosis $\mathrm{C}$ patients and cirrhosis B patients with low necro-inflammatory grading (Metavir-A1, 3 patients) and high necroinflammatory grading (Metavir-A3, 3 patients) according to the French Metavir Scoring System.

In HCV patients, the frequencies of both CD158a, $\mathrm{h}^{+}$and CD158b,j $\mathrm{j}^{+}$NK cells were significantly higher among blood lymphocytes relative to the liver infiltrating lymphocytes (mean values: $19.2 \%$ vs $7.6 \%-p<0.001,30.0 \%$ vs $15.0 \% \quad p<0.001$, respectively) (Fig.4B,C), whereas $\mathrm{NKG}_{2} \mathrm{~A}^{+} \mathrm{NK}$ cell frequency was comparable in liver and blood NK cells $(58.0 \%$ vs $54.5 \%, N S$ ) (Fig.4A). In contrast, in the liver of HBV patients, the frequency of CD158a, $\mathrm{h}^{+}$, CD158b, $j^{+}$and NKG2A NK cells appeared similar to those observed in the blood (mean values: $26.3 \%$ vs $27.5 \%$ - NS, $30.9 \%$ vs $28.6 \%$ NS, $24.7 \%$ vs $26.1 \%$ - NS, respectively) (Fig.4B,C).

In HCV patients, the frequency of intrahepatic CD158a, $\mathrm{h}^{+}$and $\mathrm{CD} 158 \mathrm{~b}, \mathrm{j}^{+} \mathrm{NK}$ cells appeared significantly lower than those observed in HBV patients $(7.6 \%$ vs $27.5 \%, p<0.001$ and $15.0 \%$ vs $28.6 \% \quad-\quad p<0.005$ respectively). Inversely, the frequency of intra-hepatic $\mathrm{NKG}_{2} \mathrm{~A}^{+} \mathrm{NK}$ cells was significantly higher in $\mathrm{HCV}$ than in HBV patients $(58 \%$ vs $26.1 \%$ $p<0.005)$. Taken together, our findings revealed striking modifications in the tissue distribution of these NK cell subsets in patients with persistent $\mathrm{HCV}$ or $\mathrm{HBV}$ infection, in particular: i) reduced proportions of $\mathrm{CD} 158 \mathrm{a}, \mathrm{h}^{+}$and CD158b, $\mathrm{j}^{+}$liver infiltrating NK lymphocytes among HCV patients, at different stages of the viral infections, even in patients with low Metavir Activity score (data not shown) and, ii) alterations in intra-hepatic $\mathrm{NKG}^{+} \mathrm{A}^{+} \mathrm{NK}$ cells in HBV patients (Fig.4A).

\section{Analysis of perforin expression among intra- hepatic CD3 $\mathrm{CD}^{-} 6^{+} \mathrm{NK}$ cells.}

To provide further insights in the potential cytotoxicity of NK cells, we studied the cellular contents of perforin in intra-hepatic $\mathrm{CD}^{2} 6^{+}$cells of $5 \mathrm{HCV}$ patients and $2 \mathrm{HBV}$ patients. In $\mathrm{HCV}$ patients, $67.43 \pm 6.09 \%$ of $\mathrm{CD}^{-} \mathrm{CD} 56^{+}$cells were perforin positive (Fig.1F), suggesting that a large amount of $\mathrm{CD} 56^{+}$cells showed a cytotoxic potential. As in $\mathrm{HCV}$ patients, $\mathrm{NKG}_{2} \mathrm{~A}^{+}$cells represented the major subset of $\mathrm{CD} 3^{-} \mathrm{CD} 56^{+} \mathrm{NK}$ cells, we investigated their perforin content. $83.77 \pm 45.36 \%$ of these cells were perforin positive (Fig.1G) indicating that the subset of NK cells expressing NKG2A marker had the cytolytic potential in $\mathrm{HCV}$ infected patients. Interestingly, the same analysis conducted on HBV patients revealed that only $35.48 \pm 22.17 \%$ of $\mathrm{CD} 3{ }^{-} \mathrm{CD} 56^{+}$cells were perforin positive. The low frequency of $\mathrm{CD}^{-} \mathrm{CD} 56^{+} \mathrm{NKG} 2 \mathrm{~A}^{+}$in $\mathrm{HBV}$ patients impedes accurate quantification perforin-expressing cells. In parallel, in HCV patients, the analysis of intra-hepatic cells selected for the expression $\mathrm{CD}^{+} \mathrm{CD} 56^{+}$and perforin revealed that the proportion of perforin positive cells was low (less than $10 \%$ ). These results were in agreement with our previous report indicating that the proportion of perforin positive cells among blood $\mathrm{CD} 3^{+} \mathrm{CD} 56^{+} \mathrm{T}$ cells was reduced in HCV patients (Fig.1H) [19]. 
A)

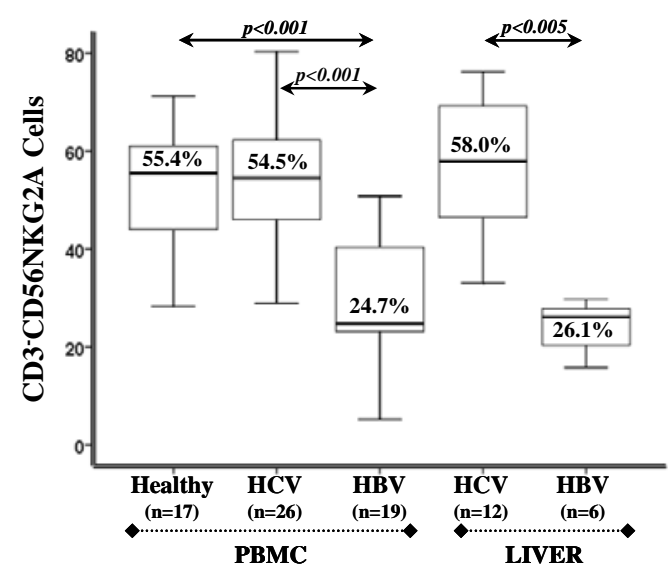

B)

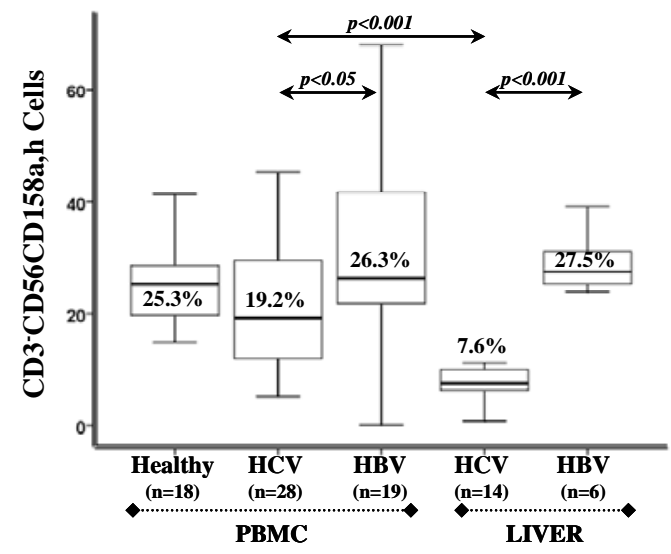

C)

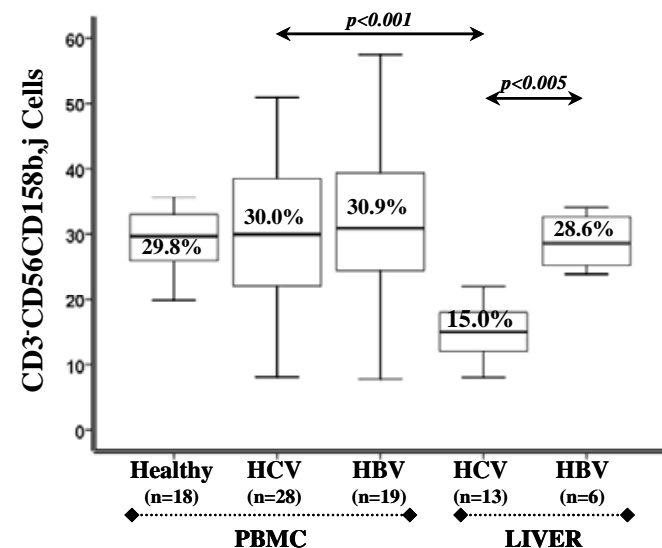

Figure 4. Frequency of $\mathrm{NKR}^{+}$cells within the total NK population $\left(\mathrm{CD}^{-} \mathrm{CD}^{-} 6^{+}\right)$The frequency of (A) NKG2A ${ }^{+}$, (B) CD158a, ${ }^{+}$and (C) $\mathrm{CD} 158 \mathrm{~b}, \mathrm{j}^{+}$cells within the total NK cells population $\left(\mathrm{CD}^{-} \mathrm{CD} 56^{+}\right)$was analyzed in blood lymphocytes for healthy control, $\mathrm{HCV}^{+}$and $\mathrm{HBV}^{+}$patients and in intra-hepatic lymphocytes for $\mathrm{HCV}^{+}$and $\mathrm{HBV}^{+}$patients by the flow cytometry.

Analysis of the frequencies of $\mathrm{CD3}^{-} \mathrm{CD} 56^{+} \mathrm{NK}$ cells subsets with clinical parameters in $\mathrm{HCV}$ and $\mathrm{HBV}$ patients.

First, we analyzed the correlation between intra-hepatic and peripheral $\mathrm{CD}^{-}$
$\mathrm{CD}^{+} 6^{+}$cells according to activity or fibrosis in $\mathrm{HCV}$ or HBV infected patients. In HCV patients, negative correlations were observed between intra-hepatic $\mathrm{CD}^{-} \mathrm{CD} 56^{+}$cells and Metavir Activity $(\mathrm{r}=-0.579, \mathrm{p}=0.006)$ or Metavir Fibrosis $(\mathrm{r}=-0.547, \mathrm{p}=0.010)$. More specifically, the frequencies of intra-hepatic $\mathrm{CD} 3{ }^{-} \mathrm{CD} 56^{+}$cells decreased with increased Metavir activity (Fig.5A) (A1/A3- $\mathrm{z}=-2.386-\mathrm{p}=0.016$ or $\mathrm{A} 2 / \mathrm{A} 3-$ $\mathrm{z}=-2.148-\mathrm{p}=0.030)$ and Metavir fibrosis scores (Fig.5B) (F0/F2, $\mathrm{z}=-1.890, \quad \mathrm{p}=0.073)$. Such correlations were not observed in peripheral cells in HCV patients and in peripheral or intrahepatic cells in HBV patients.
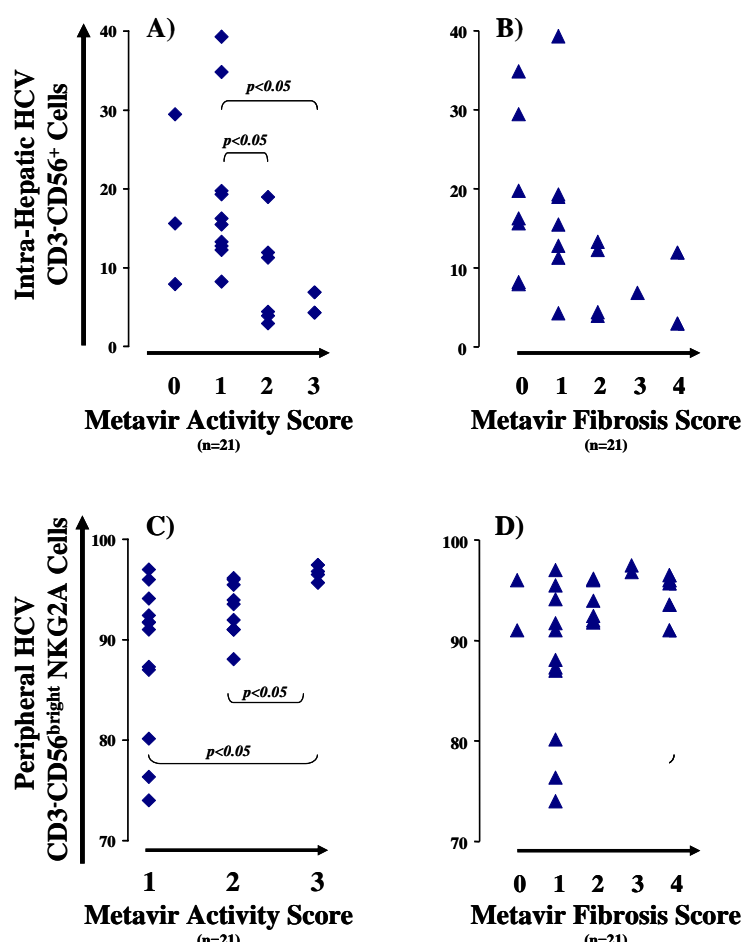

Figure 5. Correlation between intra-hepatic CD3 $^{-} \mathrm{CD}^{-}{ }^{+}$cells and peripheral $\mathrm{CD3}^{-}$ CD56 $^{\text {bright }}$ NKG2A $^{+}$cells according to the Metavir Activity Score and Metavir Fibrosis Scores in chronic Hepatitis C patients. Wilcoxon statistical tests were performed between intra-hepatic $\mathrm{CD}^{-} \mathrm{CD}^{-} 6^{+}$cells and Metavir Activity (A), Metavir Fibrosis (B). Same analysis for peripheral $\mathrm{CD}^{-}$ CD56 ${ }^{\text {bright }}$ NKG2A cells and Metavir Activity (C), or Metavir Fibrosis (D).

Second, we found that the percentage of CD3 ${ }^{-C D} 56^{\text {bright }}$ NK cells with NKG2A expression was positively associated with the severity of both necroinflammation $(\mathrm{r}=0.545$, $p<0.01)$ and fibrosis $(r=0.454, p<0.05)$ in $\mathrm{HCV}$ patients. Moreover, the number of blood $\mathrm{CD}^{-}$ 
CD56 $6^{\text {bright }} \mathrm{NKG} \mathrm{A}^{+}$cells increased also with the severity of disease in these patients. Indeed, positive correlations were observed between these peripheral cells and Activity (A1/A3$\mathrm{z}=2.550 ; \mathrm{p}=0.008$ and $\mathrm{A} 2 / \mathrm{A} 3-\mathrm{z}=2.472 ; \mathrm{p}=0.011$ ) (Fig.5C) and also with fibrosis (F1/F3- $\mathrm{Z}=1.927$; $\mathrm{p}=0.052$ and $\mathrm{F} 1 / \mathrm{F} 4-\mathrm{z}=1.974 ; \mathrm{p}=0.051$ ) (Fig.5D). It is important to note that the correlations mentioned above between the subsets of NK cells and severity of disease, were not found in the case of HBV patients. Concerning HCV patients, we observed a negative association $(\mathrm{r}=$ $-0.540, p<0.01)$ between the frequency of $\mathrm{CD}^{-}$ $\mathrm{CD}^{+} 6^{+} \mathrm{NKG}^{-\mathrm{A}^{+}}$cells and the serum viral load (Fig.6A). This comparable negative correlation was also detectable in these patients when the analysis was restricted to the blood $\mathrm{CD}^{-}$ $\mathrm{CD}^{\mathrm{dim}}{ }^{\mathrm{dim}}$ subset $(\mathrm{r}=-0.441, p<0.05$ (Fig.6B). In HBV infected patients, we did not observe any correlation between viral load and peripheral NK cell subsets. However, in the six HBV infected patients in whom viral load and intrahepatic flow cytometric data were available, a negative correlation between $\mathrm{CD}^{-} \mathrm{CD}^{-} 6^{+}$or $\mathrm{CD}^{-}$ $\mathrm{CD}^{2} 6^{\mathrm{dim}} \mathrm{NKG} 2 \mathrm{~A}^{+}$and viral load $(\mathrm{r}=-0.900$ $p<0.05$ ) was found.
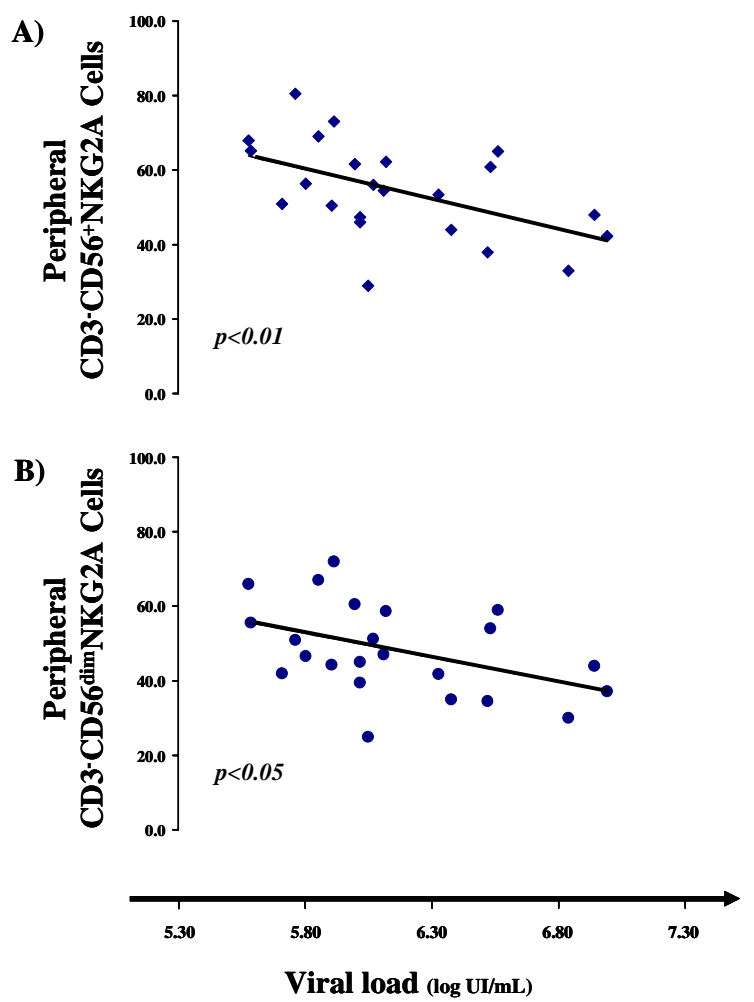

Figure 6. Correlation between $\mathrm{CD}^{-}$ $\mathrm{CD}^{+}{ }^{+} \mathrm{NKG}^{+} \mathrm{A}^{+}$cells and viral load from PBMCs of $\mathrm{HCV}^{+}$Patients. Spearman statistical tests were performed between viral load and $\mathrm{CD}^{-}{ }^{-} \mathrm{CD} 56^{+} \mathrm{NKG} 2 \mathrm{~A}^{+}$cells (A) or $\mathrm{CD}^{-}$ $\mathrm{CD}^{\mathrm{dim}}{ }^{\mathrm{dim}} \mathrm{NK} 2 \mathrm{~A}^{+}$cells (B).

\section{Discussion}

Ours data confirm a significant reduction in NK cell frequency and a quantitative imbalance of the CD56 $6^{\text {bright }}$ and CD56 $6^{\mathrm{dim}}$ subsets within the total NK cell population in $\mathrm{HCV}$ and HBV infected patients [14, 16]. In HCV infections, under proinflammatory conditions, it has also been reported that $\mathrm{CD}^{-} \mathrm{CD} 56^{\mathrm{dim}} \mathrm{NK}$ cells are more susceptible to apoptosis compared to $\mathrm{CD} 3^{-\mathrm{CD}} 56^{\text {bright }} \mathrm{NK}$ cells, under inflammatory conditions and that this can contribute to altered maintenance of $\mathrm{CD}^{-} \mathrm{CD} 56^{\mathrm{dim}} \mathrm{NK}$ cells in infectious diseases [23]. In healthy individuals, there are clearly more apoptotic, activated CD56 ${ }^{\mathrm{dim}}$ cells among blood NK cells compared to their $\mathrm{CD} 3^{-\mathrm{CD}} 56^{\text {bright }}$ counterparts thereby suggesting that a differential susceptibility to cell death is a natural feature of these two subsets [13]. Here, neither decreases of CD56 cell numbers nor differences in $\mathrm{CD}^{-}$ CD56 $6^{\text {bright }} / \mathrm{CD}^{-}{ }^{-} \mathrm{CD} 56^{\mathrm{dim}}$ ratios were observed in HBV patients, thereby suggesting that the proinflammatory environment is not sufficient to explain the altered $\mathrm{CD} 3^{-} \mathrm{CD} 56^{\mathrm{dim}} / \mathrm{CD} 3^{-} \mathrm{CD} 56^{\text {bright }}$ ratio in the HCV group. The clear differences in NK cell frequencies and the expression of differential $\mathrm{CD} 3^{-\mathrm{CD}} 56^{\mathrm{dim} / \mathrm{CD}} 3^{-\mathrm{CD}} 56^{\text {bright }}$ ratio in both viral infections strongly supports that $\mathrm{HCV}$ itself may able to alter significantly the activation, proliferation of NK cells $[4,5,24]$.

The examination of perforin contents in $\mathrm{CD}^{-}{ }^{-} \mathrm{CD} 56^{+}$cells in both pathologies show a striking difference: $\mathrm{CD} 56^{+}$cells in $\mathrm{HCV}$ patients are enriched in perforin whereas in HBV patients a low number of $\mathrm{CD} 3{ }^{-} \mathrm{CD} 56^{+}$perforin $^{+}$cells are observed. Thus, in HCV patients the frequencies of $\mathrm{CD}^{-} \mathrm{CD}^{-} 6^{+}$cells are lower than in $\mathrm{HBV}$ patients, but these $\mathrm{CD} 3^{-} \mathrm{CD} 56^{+}$cells contain more cytolytic proteins which able to lyse the infected cells. One can hypothesize that $\mathrm{HCV}$ may be able to negatively regulate proliferation and differentiation of $\mathrm{CD} 56^{+}$cells but not their toxicity.

NK cell activation may be impaired and/or prevented by cell surface inhibitory receptors expressed by NK cells [27]. We did not observe any significant change in the frequencies of both CD158a, $\mathrm{h}^{+}$and CD158b,j ${ }^{+}$ cells in the blood of HCV and HBV patients as depicted by others in the patients with chronic $\mathrm{HCV}$ and hepatocellular carcinoma [16, 28]. Instead, we report a strong alteration in the frequencies of $\mathrm{CD}^{-} \mathrm{CD} 56^{+} \mathrm{NK}$ cells expressing $\mathrm{CD} 158 \mathrm{a}, \mathrm{h}^{+}$or $\mathrm{CD} 158 \mathrm{~b}, \mathrm{j}^{+}$in the liver of $\mathrm{HCV}$ patients but not in HBV patients. The role of 
these subsets of NK cells in the liver has not been clearly determined, although they represent a significant proportion of intra-hepatic NK cells in healthy donors [28] As the $\mathrm{CD}^{-}$ $\mathrm{CD} 66^{+} \mathrm{CD} 158 \mathrm{a}, \mathrm{h}^{+}$and $\mathrm{CD} 158 \mathrm{~b}, \mathrm{j}^{+}$are more expressed in $\mathrm{CD}^{-} \mathrm{CD} 56^{\mathrm{dim}}$ than in $\mathrm{CD}^{-}$ CD56 $6^{\text {bright }}[16,17]$ the decrease of these subsets in the liver of $\mathrm{HCV}$ patients, again underlines that HCV may interfere with the activation/differentiation of intra-hepatic $\mathrm{CD}^{-}$ $\mathrm{CD}^{\mathrm{dim}}{ }^{\mathrm{dim}}$ cells subset which is generally more cytotoxic. In type 2 transmembrane proteins, no significant change in the frequencies of liver infiltrating $\mathrm{NKG}_{2} \mathrm{~A}^{+}$cells were detected in $\mathrm{HCV}$ patients, while, they are significantly reduced in the blood and liver compartments of HBV patients. Taken together, our results suggest that both viruses differentially interfere with NK cell homeostasis. This point requires further analysis in particular by investigating additional receptors for each family to determine if the viruses have a tropism for one or another of these receptors.

Statistical analysis indicates that the peripheral $\mathrm{CD}^{-} \mathrm{CD} 56^{\text {bright }} \mathrm{NKG} \mathrm{A}^{+}$cells are positively correlated with necro-inflammatory activity score in $\mathrm{HCV}$ patients but not HBV patients. It has been reported that NKG2A expression correlates with CD94 and that high levels of CD94 expression (a well established feature of $\mathrm{CD} 3^{-\mathrm{CD} 56^{\text {bright }}} \mathrm{NK}$ cells) is associated with an enhanced resistance of NK lymphocytes to cell death [29]. One can argue that under constant HCV-mediated inhibition combined to cell-cell interaction(s) and/or local cytokine production a level of selective persistence/retention of specific intra-hepatic NK cell subsets lose the ability to undergo differentiation beyond the $\mathrm{CD} 3^{-} \mathrm{CD} 56^{\text {bright }}$ stage but acquire higher cytotoxic activity.

This hypothesis is supported by our data showing that the frequency of intra-hepatic $\mathrm{CD}^{-}$ $\mathrm{CD}^{2} 6^{+}$Perforin $^{+}$cells in $\mathrm{HCV}$ patients is higher than the equivalent counterpart in HBV patients. In summary, our analysis indicates that a high necro-inflammatory activity score is associated to a high frequency of $\mathrm{CD} 3{ }^{-} \mathrm{CD} 56^{\text {bright }} \mathrm{NKG} 2 \mathrm{~A}^{+}$ cells in the peripheral blood of HCV patients. We thus propose that the quantitative assessment of the $\mathrm{CD}^{-} \mathrm{CD} 56^{\text {bright }} \mathrm{NKG}^{-\mathrm{A}^{+}} \mathrm{NK}$ cell subpopulation has potential for incorporation to current grading schemes of persistent $\mathrm{HCV}$ infection.

Interestingly, we found a negative correlation between $\mathrm{CD}^{-} \mathrm{CD} 56^{+} \mathrm{NKG} 2 \mathrm{~A}^{+}$cells and viral load in HCV and HBV patients. To pin point this correlation, we observed that the viral load was correlated negatively with $\mathrm{CD}^{-}$ $\mathrm{CD}^{2} 6^{\mathrm{dim}} \mathrm{NKG} 2 \mathrm{~A}^{+}$cells subset. Taking in account that i) $\mathrm{CD}^{2} 6^{+} \mathrm{NKG} 2 \mathrm{~A}^{+}$cells represent half of the CD56 ${ }^{+} \mathrm{NK}$ cells and, ii) as we discussed above that $\mathrm{HCV}$ tends to control negatively the frequency of $\mathrm{CD} 56^{+} \mathrm{NK}$ cells during the chronic infection, it is not surprising that in patients with a high level of virus (HCV), the frequency of $\mathrm{CD}^{-} \mathrm{CD} 56^{+} \mathrm{NKG} 2 \mathrm{~A}^{+}$cells is low. In the $6 \mathrm{HBV}$ patients, we observed high decrease of ${ }^{2} D 56{ }^{+} \mathrm{NKG}_{2} \mathrm{~A}^{+}$cells and a negative correlation between viral load and intra-hepatic CD $3^{-} \mathrm{CD} 56^{+}$ cells or $\mathrm{CD}^{-} \mathrm{CD} 56^{\mathrm{dim}} \mathrm{NKG} 2 \mathrm{~A}^{+}$cells. Taken together, these data suggest that both viruses have tropism to NKG2A expressing $\mathrm{CD}^{-}$ CD56 ${ }^{\text {dim }}$ cells subset.

Finally, our analyses identify two subsets of NK cells with potential as new markers for disease grading in HCV infection. First, the frequency of circulating $\mathrm{CD}^{-}$ CD56 $6^{\text {bright }} \mathrm{NKG} 2 \mathrm{~A}^{+}$cells is correlated with high score of necro-inflammatory activity and second, the frequency of circulating $\mathrm{CD}^{-}$ CD56 ${ }^{\mathrm{dim}} \mathrm{NKG} 2 \mathrm{~A}^{+}$cells which is negatively correlated with viral load in both infections. In addition, differential $\mathrm{CD} 3^{-} \mathrm{CD} 56^{\text {bright }} / \mathrm{CD}^{-}$ $\mathrm{CD} 56^{\mathrm{dim}}$ ratios and frequency of $\mathrm{CD} 3^{-} \mathrm{CD} 56^{+}$ subsets in the liver of HCV and HBV patients highlighted that both viruses may use some different strategy to target immune system.

\section{Acknowledgements}

We are grateful to the patients who enrolled in this study for their cooperation. This work was supported by grants from INSERM , from the Agence Nationale pour la Recherche sur le Sida (ANRS) and from Pole de compétitivité LyonBiopole. P.B. was supported by ANRS; M.R. from Higher Education Commission of Pakistan and X.C. by Région-Rhône Alpes "Cluster 10". The authors thank Dr Mary Callanan for reading this manuscript. 


\section{References}

[1] Guidotti LG, Chisari FV. Immunobiology and pathogenesis of viral hepatitis. Annu Rev Pathol 2006;1:23-61. [2]Lanier LL. NK cell recognition. Annu Rev Immunol 2005;23:225-274.

[3] Orange JS, Fassett MS, Koopman LA, Boyson JE, Strominger JL. Viral evasion of natural killer cells. Nat Immunol 2002;3:10061012.

[4] Crotta S, Stilla A, Wack A, D'Andrea A, Nuti S, D'Oro U, et al. Inhibition of natural killer cells through engagement of CD81 by the major hepatitis $\mathrm{C}$ virus envelope protein. J Exp Med 2002;195:35-41.

[5] Tseng CT, Klimpel GR. Binding of the hepatitis $\mathrm{C}$ virus envelope protein $\mathrm{E} 2$ to $\mathrm{CD} 81$ inhibits natural killer cell functions. J Exp Med 2002;195:43-49.

[6] Foy E, Li K, Wang C, Sumpter R, Jr., Ikeda M, Lemon SM, et al. Regulation of interferon regulatory factor- 3 by the hepatitis $\mathrm{C}$ virus serine protease. Science 2003;300:11451148.

[7] Taylor DR, Shi ST, Romano PR, Barber GN, Lai MM. Inhibition of the interferoninducible protein kinase PKR by HCV E2 protein. Science 1999;285:107-110.

[8] Guidotti LG, Morris A, Mendez H, Koch $\mathrm{R}$, Silverman RH, Williams BR, et al. Interferonregulated pathways that control hepatitis $\mathrm{B}$ virus replication in transgenic mice. J Virol 2002;76:2617-2621.

[9] Herzer K, Falk CS, Encke J, Eichhorst ST, Ulsenheimer A, Seliger B, et al. Upregulation of major histocompatibility complex class I on liver cells by hepatitis $\mathrm{C}$ virus core protein via p53 and TAP1 impairs natural killer cell cytotoxicity. J Virol 2003;77:82998309.

[10] Zhou DX, Taraboulos A, Ou JH, Yen TS. Activation of class I major histocompatibility complex gene expression by hepatitis B virus. J Virol 1990;64:4025-4028.

[11] Li Y, Zhang T, Ho C, Orange JS, Douglas SD, Ho WZ. Natural killer cells inhibit hepatitis $\mathrm{C}$ virus expression. J Leukoc Biol 2004;76:1171-1179.

[12] Dunn C, Brunetto M, Reynolds G, Christophides T, Kennedy PT, Lampertico P, et al. Cytokines induced during chronic hepatitis $\mathrm{B}$ virus infection promote a pathway for NK cell- mediated liver damage. J Exp Med 2007;204:667-680.

[13] Lin AW, Gonzalez SA, CunninghamRundles S, Dorante G, Marshall S, Tignor A, et al. CD56(+dim) and CD56(+bright) cell activation and apoptosis in hepatitis $\mathrm{C}$ virus infection. Clin Exp Immunol 2004;137:408-416. [14] Meier UC, Owen RE, Taylor E, Worth A, Naoumov N, Willberg C, et al. Shared alterations in NK cell frequency, phenotype, and function in chronic human immunodeficiency virus and hepatitis $\mathrm{C}$ virus infections. J Virol 2005;79:12365-12374.

[15] Morishima C, Paschal DM, Wang CC, Yoshihara CS, Wood BL, Yeo AE, et al. Decreased NK cell frequency in chronic hepatitis $\mathrm{C}$ does not affect ex vivo cytolytic killing. Hepatology 2006;43:573-580.

[16] Golden-Mason L, Madrigal-Estebas L, McGrath E, Conroy MJ, Ryan EJ, Hegarty JE, et al. Altered natural killer cell subset distributions in resolved and persistent hepatitis $\mathrm{C}$ virus infection following single source exposure. Gut 2008;57:1121-1128.

[17] Cooper MA, Fehniger TA, Turner SC, Chen KS, Ghaheri BA, Ghayur T, et al. Human natural killer cells: a unique innate immunoregulatory role for the CD56(bright) subset. Blood 2001;97:3146-3151.

[18] Jacobs R, Hintzen G, Kemper A, Beul K, Kempf S, Behrens G, et al. CD56bright cells differ in their KIR repertoire and cytotoxic features from CD56dim NK cells. Eur J Immunol 2001;31:3121-3127.

[19] Bonorino P, Leroy V, Dufeu-Duchesne T, Tongiani-Dashan S, Sturm N, Pernollet M, et al. Features and distribution of CD8 T cells with human leukocyte antigen class I-specific receptor expression in chronic hepatitis $\mathrm{C}$. Hepatology 2007;46:1375-1386.

[20] Leroy V, Vigan I, Mosnier JF, DufeuDuchesne T, Pernollet M, Zarski JP, et al. Phenotypic and functional characterization of intrahepatic T lymphocytes during chronic hepatitis C. Hepatology 2003;38:829-841. [21] Vigan I, Jouvin-Marche E, Leroy V, Pernollet M, Tongiani-Dashan S, Borel E, et al. $\mathrm{T}$ lymphocytes infiltrating the liver during chronic hepatitis $\mathrm{C}$ infection express a broad range of T-cell receptor beta chain diversity. $\mathrm{J}$ Hepatol 2003;38:651-659.

[22] Pernollet M, Jouvin-Marche E, Leroy V, Vigan I, Zarski JP, Marche PN. Simultaneous evaluation of lymphocyte subpopulations in the 
liver and in peripheral blood mononuclear cells of $\mathrm{HCV}$-infected patients: relationship with histological lesions. Clin Exp Immunol 2002; 130:518-525.

[23] Schierloh P, Yokobori N, Aleman M, Musella RM, Beigier-Bompadre M, Saab MA, et al. Increased susceptibility to apoptosis of CD56dimCD16+ NK cells induces the enrichment of IFN-gamma-producing CD56bright cells in tuberculous pleurisy. $\mathrm{J}$ Immunol 2005;175:6852-6860.

[24] Pileri P, Uematsu Y, Campagnoli S, Galli G, Falugi F, Petracca R, et al. Binding of hepatitis $\mathrm{C}$ virus to CD81. Science 1998;282:938-941.

[25] Melhem A, Muhanna N, Bishara A, Alvarez CE, Ilan Y, Bishara T, et al. Antifibrotic activity of NK cells in experimental liver injury through killing of activated HSC. J Hepatol 2006;45:60-71.

[26] Radaeva S, Sun R, Jaruga B, Nguyen VT, Tian Z, Gao B. Natural killer cells ameliorate liver fibrosis by killing activated stellate cells in NKG2D-dependent and tumor necrosis factor-related apoptosis-inducing ligand-dependent manners. Gastroenterology 2006; 130:435-452.

[27] Long EO, Burshtyn DN, Clark WP, Peruzzi M, Rajagopalan S, Rojo S, et al. Killer cell inhibitory receptors: diversity, specificity, and function. Immunol Rev 1997;155:135-144. [28] Yuen MF, Norris S. Expression of inhibitory receptors in natural killer (CD3()CD56(+)) cells and CD3(+)CD56(+) cells in the peripheral blood lymphocytes and tumor infiltrating lymphocytes in patients with primary hepatocellular carcinoma. Clin Immunol 2001;101:264-269.

[29] Gunturi A, Berg RE, Forman J. Preferential survival of CD8 T and NK cells expressing high levels of CD94. J Immunol 2003;170:1737-1745. 